\title{
Analisis Keefektifan Ekoenzim sebagai Pembersih Kandang Ayam dari Limbah Buah Jeruk (Citrus sp.)
}

\author{
Analysis of Ecoenzymes Effectiveness as Cleaning Chicken Coops from Citrus Fruit Waste (Citrus sp.)
}

\author{
A. Mahdia ${ }^{1}$, P. A. Safitri ${ }^{1}$, R. F. Setiarini ${ }^{1}$, V. F. A. Maherani ${ }^{1}$, M. N. Ahsani ${ }^{1}$, \& M. S. Soenarno ${ }^{2 *}$ \\ ${ }^{1}$ Program Studi Teknologi Hasil Ternak, Departemen Ilmu Produksi dan Teknologi Peternakan, Fakultas \\ Peternakan, Institut Pertanian Bogor \\ ${ }^{2}$ Departemen Ilmu Produksi dan Teknologi Peternakan, Fakultas Peternakan, Institut Pertanian Bogor \\ Jl. Agatis, Kampus IPB Darmaga Bogor 16680, Indonesia \\ *Corresponding author: mochamadsoenarno@apps.ipb.ac.id \\ (Received 12-09-2021; Revised 14-10-2021; Accepted 24-12-2021)
}

\begin{abstract}
Sanitation of the cage usually requires a sanitizer containing a powerful cleaning fluid to sterilize the cage. Materials commonly used for cage sanitation are detergent or disinfectants used to eradicate pathogenic microorganisms that cause bacteria, fungi, or other microorganisms. Eco enzyme is an alternative natural cleaning agent derived from fresh fruit waste through fermentation. This study aimed to make eco enzymes for cleaning chicken coops from citrus waste, characterize the microbiological eco enzymes, and test the effectiveness of eco enzymes as chicken coop cleaners. Eco enzymes from fresh citrus waste after a 3-month fermentation period contained bacteria and fungi of $1.9 \times 10^{6} \mathrm{CFU} / \mathrm{ml}$ and $8.5 \times 10^{5} \mathrm{CFU} /$ $\mathrm{ml}$, respectively, with a pH of $3.39 \pm 0.023$. The eco enzyme of cage cleaning fluid from citrus waste (Citrus sp.) can inhibit the growth of Escherichia coli and Staphylococcus aureus through confrontation tests in the laboratory. Testing the effectiveness of eco enzymes in chicken coops can reduce the number of bacteria five times more than detergents for the same area.
\end{abstract}

Keywords: Chicken coop, confrontation test, Escherichia coli, fermentation, Staphylococcus aureus

\begin{abstract}
ABSTRAK
Sanitasi kandang biasanya memerlukan alat sanitizer berisi cairan pembersih yang ampuh untuk mensterilkan kandang. Bahan yang biasa digunakan untuk sanitasi kandang ialah sabun detergen atau desinfektan yang digunakan untuk membasmi mikroorganisme patogen penyebab baik bakteri, jamur, atau mikroorganisme lainnya. Ekoenzim merupakan salah satu alternatif bahan pembersih alami yang berasal dari limbah buah segar melalui proses fermentasi. Tujuan dari penelitian ini yaitu membuat ekoenzim pembersih kandang ayam dari limbah jeruk, melakukan karakterisasi mikrobiologi ekoenzim, dan menguji efektivitas ekoenzim sebagai pembersih kandang ayam. Ekoenzim dari limbah jeruk segar setelah masa fermentasi 3 bulan mengandung bakteri dan cendawan masing-masing sebesar $1.9 \times 10^{6} \mathrm{CFU} / \mathrm{ml}$ dan $8.5 \times 10^{5} \mathrm{CFU} / \mathrm{ml}$ dengan $\mathrm{pH} 3.39 \pm 0.023$. Ekoenzim cairan pembersih kandang dari limbah jeruk (Citrus sp.) memiliki kemampuan untuk menghambat pertumbuhan Escherichia coli dan Staphylococcus aureus melalui uji konfrontasi di laboratorium. Pengujian efektivitas ekoenzim di kandang ayam dapat menurunkan jumlah bakteri lima kali lebih banyak dibandingkan detergen untuk luasan yang sama.
\end{abstract}

Kata kunci: Escherichia coli, fermentasi, kandang ayam, Staphylococcus aureus, uji konfrontasi 


\section{PENDAHULUAN}

Sanitasi kandang bertujuan untuk menjaga kebersihan bangunan tempat tinggal ternak atau kandang dan lingkungannya dalam rangka menjaga kesehatan ternak dan mencegah penyebaran bibit penyakit yang dapat menyerang ternak (Kasnodihardjo dan Fiskarini 2013; Azizah dan Zuroida 2018). Sanitasi kandang biasanya memerlukan alat sanitizer berisi cairan pembersih yang ampuh untuk mensterilkan kandang. Bahan yang biasa digunakan untuk sanitasi kandang ialah sabun detergen atau desinfektan yang digunakan untuk membasmi mikroorganisme patogen penyebab baik bakteri, jamur, atau mikroorganisme lainnya. Penggunaan pembersih kandang dari bahan kimia seperti formalin dikhawatirkan akan memberikan efek toksik (racun) pada hewan ternak (Azizah dan Zuroida 2018). Penggunaan bahan alami sebagai pengganti bahan kimia detergen dapat menjadi alternatif dalam pembuatan cairan pembersih kandang. Salah satu alternatif pembersih alami yaitu ekoenzim.

Ekoenzim merupakan salah satu alternatif bahan pembersih alami yang berasal dari limbah sayur dan buah segar melalui proses fermentasi (Rasit et al. 2019). Proses fermentasi dari buah-buhan dan sayuran dalam kondisi anaerob dapat dilakukan oleh khamir, seperti Saccharomyces cerevisiae yang menghasilkan etanol, dan bakteri seperti Lactobacillus sp. dan Acetobacter sp. menghasilkan berbagai asam organik. Sementara kapang berperan sebagai pengurai karbohidrat, selulosa, dan hemiselulosa yang terdapat pada kulit buah (Madigan et al. 2012). Hasil penelitian Kumar et al. (2020) menunjukkan ekoenzim dari bunga segar dengan konsentrasi 10\% efektif dapat menurunkan amoniak nitrogen, fosfat, biological oxygen demands (BOD5) dari air limbah cucian rumah tangga (grey water).

Pemanfaatan ekoenzim sebagai pembersih kandang dan kajian ilmiahnya hingga kini belum dijumpai. Penelitian ini akan mengaplikasikan penggunaan limbah buah segar dari jeruk sebagai pembersih (sanitasi) kandang ayam. Bahan pembersih ini diharapkan bersifat ramah lingkungan ini, aman bagi kesehatan, dan dapat membantu para pedagang buah untuk memanfaatkan buah yang tidak laku terjual sebelum busuk untuk difermentasi menjadi bahan cair pembersih. Keuntungan menggunakan cairan pembersih dari buah lemon dan jeruk, yaitu buah ini mengandung antimikrob dan antioksidan alami, seperti vitamin $C$, asam sitrat, minyak atsiri, bioflavonoid, polifenol, kumarin, flavonoid, dan minyak-minyak volatil pada kulitnya seperti limonen $( \pm 70 \%), \alpha$-terpinen, $\alpha$-pinen, $\beta$-pinen, serta kumarin, dan polifenol (Krisnawan et al. 2017). Tujuan dari penelitian ini yaitu membuat ekoenzim pembersih kandang ayam dari limbah jeruk, melakukan karak-terisasi mikrobiologi ekoenzim, dan menguji efektivitas ekoenzim sebagai pembersih kandang ayam.

\section{MATERI DAN METODE}

\section{Materi \\ Pembuatan Ekoenzim}

Cairan pembersih terdiri atas komponen limbah kulit buah lemon dan jeruk, gula merah, dan air bersih dengan perbandingan 3:1:10 (Kumar et al. 2020). Ketiganya dicampur dan dihaluskan menggunakan mesin blender. Campuran dimasukkan ke dalam jerigen yang bersih hingga maksimal $60 \%$ dari volume. Jerigen berisi cairan pembersih ditutup rapat dan disimpan di tempat yang bersih, kering, dan tidak terkena sinar matahari. Proses pembuatan cairan pembersih berlangsung selama 3 bulan hingga dihasilkan cairan jernih berwarna coklat.

\section{Metode}

\section{Pengujian Ekoenzim di Laboratorium}

Cairan pembersih diuji secara mikrobiologi di laboratorium. Pengukuran $\mathrm{pH}$ menggunakan alat $\mathrm{pH}$ meter dilakukan pada sampel cairan pembersih sebanyak $100 \mathrm{ml}$ dan 5 kali ulangan, sampel deterjen yang dibuat dengan melarutkan $0.01 \mathrm{~g}$ deterjen pada $100 \mathrm{ml}$ aquades, dan sampel air sebanyak $100 \mathrm{ml}$. Penghitungan jumlah bakteri dan cendawan dilakukan dengan metode total plate count (TPC) dan metode cawan tuang (pour plate) dilakukan untuk mengetahui jenis mikrob yang terkandung di dalam cairan pembersih. Uji ini diawali dengan pengenceran bertingkat cairan pembersih yaitu pada tingkat pengenceran $10^{-4}, 10^{-5}$, $10^{-6}, 10^{-7}$, dan $10^{-8}$ menggunakan larutan pengencer larutan fisiologis $(\mathrm{NaCl} 0.85 \%)$. Hasil pengenceran dipindahkan ke cawan sebanyak $0.2 \mathrm{ml}$ dengan teknik duplo. Media cawan yang digunakan, yaitu Plate Count Agar (PCA) dan Potato Dextrose Agar (PDA) hasil sterilisasi dengan autoklaf $121{ }^{\circ} \mathrm{C}$, tekanan 1 atm, selama 15 menit dan dituangkan sebanyak $\pm 20 \mathrm{ml}$ pada masing-masing cawan. Setiap cawan diinkubasi pada suhu $37^{\circ} \mathrm{C}$ selama 24 jam sebelum digunakan untuk menumbuhkan mikrob. Media cawan PCA digunakan untuk menumbuhkan bakteri dan PDA untuk menumbuhkan cendawan masing-masing dari hasil pengenceran serial $10^{-4}$, $10^{-5}, 10^{-6}, 10^{-7}$, dan $10^{-8}$ masing-masing tiga ulangan. Setelah 24 jam, dilakukan penghitungan mikrob yang tumbuh pada setiap media.

Uji konfrontasi dilakukan untuk mengetahui efektivitas cairan pembersih dalam menghambat pertumbuhan bakteri dari kelompok gram positif dan gram negatif. Bakteri uji yang digunakan yaitu Staphylococcus aureus (gram positif) dan Escherichia coli (gram negatif). Media Muller Hinton Agar (MHA) steril sebanyak \pm 20 $\mathrm{ml}$ disiapkan pada cawan petri. Setelah media memadat dilakukan pembagian dengan teknik kuadran untuk perlakuan cairan uji, yaitu: cairan pembersih, detergen, air, dan kosong tanpa perlakuan. Bakteri yang telah diremajakan disebar dalam media. Selanjutnya pada masing-masing kuadran diletakkan cakram dengan diameter $6 \mathrm{~mm}$ yang telah direndam dalam cairan uji selama 30 menit. Cawan diinkubasi pada suhu $37^{\circ} \mathrm{C}$ selama $24-48$ jam. Setelah $24-$ 48 jam dilakukan pengukuran diameter zona bening yang terbentuk di sekeliling cakram. Semakin besar zona hambat menandakan semakin tingginya efektivitas cairan dalam menghambat pertumbuhan bakteri uji. 


\section{Uji Efektivitas Kemampuan Ekoenzim untuk Membersihkan Kandang Ayam}

Kandang ayam berukuran $6.5 \mathrm{~m}$ x $3 \mathrm{~m}$ disiapkan dan dibagi menjadi berukuran $2.16 \mathrm{~m} \times 1 \mathrm{~m}$ untuk masingmasing perlakuan. Usapan atau swab menggunakan batang kapas yang dililit pada ujung tusuk sate serupa cotton bud steril. Usapan pada area berukuran $10 \mathrm{~cm}$ x $10 \mathrm{~cm}$. Pada riset ini digunakan hewan ternak ayam yang diberi pakan selama 2-3 hari untuk mengkondisikan kandang menjadi kotor sebelum dilakukan pengambilan sampel dengan teknik $s w a b$. Sampel hasil $s w a b$ dibawa ke laboratorium untuk diuji dengan metode TPC.

\section{HASIL DAN PEMBAHASAN}

\section{Karakteristik Ekoenzim Pembersih Kandang}

Cairan ekoenzim setelah proses fermentasi selama tiga bulan berwarna kuning kecoklatan beraroma asam segar (seperti aroma asam yang dihasilkan oleh jeruk) serta mengandung endapan berwarna kuning (Gambar 1). Uji pH pada masing-masing cairan uji menunjukkan bahwa cairan pembersih yang dibuat bersifat asam, deterjen bersifat basa, dan air bersifat asam (Tabel 1).
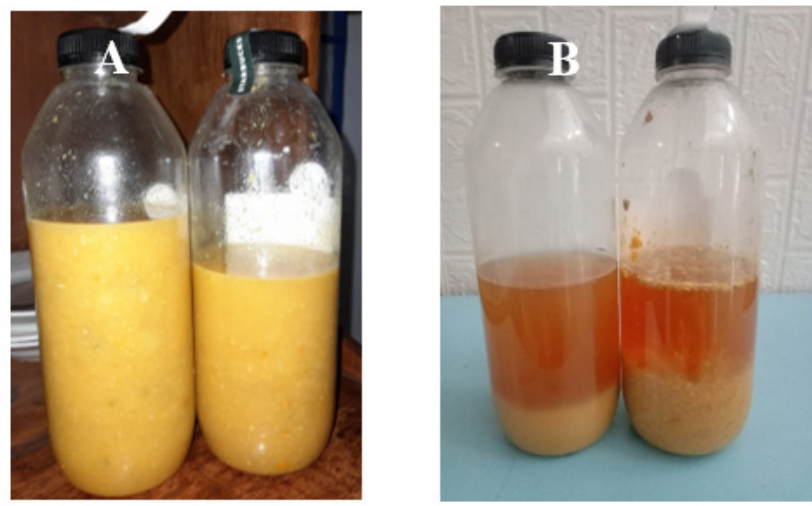

Gambar 1. Ekoenzim sebelum (A) dan setelah masa fermentasi 3 bulan (B)

Tabel 1. Hasil uji pH pada cairan pembersih ekoenzim, deterjen, dan air

\begin{tabular}{ccc}
\hline \multicolumn{3}{c}{$\mathrm{pH}$} \\
\hline Cairan pembersih & Deterjen & Air \\
\hline $3.39 \pm 0.023$ & $9.21 \pm 0.024$ & $5.59 \pm 0.13$ \\
\hline
\end{tabular}

Karakteristik ekoenzim setelah melewati masa fermentasi tiga bulan sesuai dengan kajian literatur yang dilakukan oleh Win (2011) bahwa fermentasi ekoenzim dapat dikatakan berhasil jika terbentuk larutan berwarna kecoklatan (warna asal gula merah) dan memiliki bau seperti buah yang digunakannya dan memiliki $\mathrm{pH}$ awam di bawah pH 4. Menurut Larasati et al. (2020), aroma asam pada cairan ekoenzim berasal dari asam organik, seperti asam asetat yang terdapat dalam cairan produk ekoenzim tersebut. Asam asetat umumnya akan memberikan rasa asam dan aroma asam pada cairan atau makanan. Asam asetat dihasilkan dari proses metabolisme bakteri yang secara alami terdapat dalam sisa buah dan sayur (Larasati et al. 2020). Asam organik merupakan kunci penting dalam penentuan keasaman. Artinya semakin tinggi kandungan asam organiknya, semakin rendah nilai $\mathrm{pH}$. Dengan demikian, ekoenzim yang memiliki nilai $\mathrm{pH}$ rendah dalam penelitian ini sebagai akibat dari kandungan asam organik yang tinggi seperti asam asetat atau asam sitrat (Etienne 2013).

\section{Pengujian Mikrobiologi Cairan Pembersih Kandang}

Hasil perhitungan jumlah bakteri dan cendawan yang terdapat pada cairan pembersih kandang ekoenzim masingmasing sebesar $1.9 \times 10^{6} \mathrm{CFU} / \mathrm{ml}$ dan $8.5 \times 10^{5} \mathrm{CFU} / \mathrm{ml}$ (Tabel 2). Hal ini menunjukkan selama pembentukan fermentasi ekoenzim ada bakteri dan cendawan yang terlibat dengan produk akhir dihasilkan asam organik (Etienne 2013).

Tabel 2. Hasil perhitungan jumlah bakteri dan cendawan dari cairan ekoenzim masa inkubasi 3 bulan

\begin{tabular}{lcc}
\hline \multicolumn{1}{c}{ Jenis } & Cendawan* & Bakteri** $^{*}$ \\
\hline Jumlah sel $(\mathrm{CFU} / \mathrm{ml})$ & $8.5 \times 10^{5}$ & $1.9 \times 10^{6}$ \\
Log sel & 5.92 & 6.27 \\
\hline$*$ Media Potato Dextrose Agar (PDA) & \\
$* *$ Media Plate Count Agar (PCA)
\end{tabular}

Uji konfrontasi adalah uji yang dilakukan bertujuan untuk melihat kemampuan suatu mikrob dalam menghambat atau bahkan membunuh bakteri pathogen. Beberapa metode yang dapat dilakukan untuk pengujian konfrontasi terhadap bakteri pathogen diantaranya menggunakan metode tuang, metode sebar dan metode gores dengan bahan serapan bakteri uji (Seniati et al. 2017).

Pengujian kemampuan cairan pembersih kandang dalam menghambat pertumbuhan bakteri dilakukan dengan cara uji konfrontasi menggunakan Escherichia coli sebagai perwakilan bakteri gram negatif dan Staphylococcus aureus sebagai perwakilan bakteri gram positif. Cairan pembersih kandang ekoenzim dapat menghambat perttumbuhan $E$. coli dan S. aureus. Akuades dan detergen juga dapat menghambat pertumbuhan kedua bakteri, namun tidak sebaik ekoenzim (Gambar 2). Akuades yang digunakan dalam penelitian ini memiliki $\mathrm{pH}$ asam $5.59 \pm 0.13$, jadi diduga kedua bakteri uji terhambat karena $\mathrm{pH}$ asam.

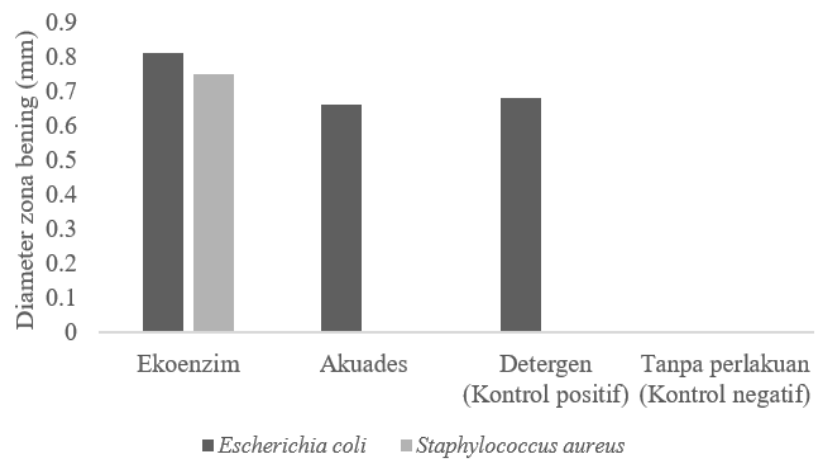

Gambar 2. Hasil pengujian konfrontasi terhadap Escherichia coli dan Staphylococcus aureus 


\section{Aplikasi dan Uji Efektivitas Cairan Ekoenzim Pembersih Kandang}

Penggunaan ekoenzim (1:10) sebagai pembersih kandang dapat mengurangi jumlah mikrob cenderung lebih banyak dibandingkan penggunaan detergen (0.1:10) dan air untuk luasan swab yang sama (Tabel 3). Kandungan dalam ekoenzim antara lain asam organik, seperti asam asetat $\left(\mathrm{H}_{3} \mathrm{COOH}\right)$, yang dapat membunuh mikrob. Selain itu juga dihasilkan $\mathrm{NO}_{3}$ (nitrat) dan $\mathrm{CO}_{3}$ (karbon trioksida) yang dibutuhkan oleh mikrob sebagai nutrien (Etienne 2013; Rochyani et al. 2020). Penggunaan detergen (0.1:10) dapat mengurangi jumlah mikrob cenderung lebih sedikit dibandingkan dengan cairan pembersih ekoenzim. Menurut Ardana (2011), desinfektan yang efektif adalah penggunaan bahan kimia dengan efektif dengan waktu kontak permukaan yang cukup. Namun demikian dosis penggunaan desinfektan yang digunakan sudah sesuai dosis anjuran $(25$ cc per $10 \mathrm{~L}$ air) (Gelgel dan Sudipa 2020). Pemberian air tidak dapat mengurangi jumlah mikrob untuk luasan yang sama (10 $\mathrm{cm}$ x $10 \mathrm{~cm}$ ) disebabkan penyemprotan air yang dilakukan kecenderungan mendapat tambahan mikrob kontaminan, sehingga nilai TPC yang dihasilkan cenderung meningkat dibandingkan dengan nilai TPC sebelum perlakuan.

Tabel 3. Jumlah sel bakteri sebelum dan sesudah pengujian pembersih kandang dengan metode swab

\begin{tabular}{lccc}
\hline \multirow{2}{*}{ Perlakuan } & \multicolumn{3}{c}{ Jumlah sel (Log sel) } \\
\cline { 2 - 4 } & $\begin{array}{c}\text { Cairan } \\
\text { pembersih }\end{array}$ & Deterjen & Air \\
\hline Sebelum & 7.51 & 7.93 & 7.07 \\
Sesudah & 6.34 & 7.53 & 7.11 \\
Pengurangan jumlah bakteri & 1.17 & 0.40 & -0.04 \\
$\begin{array}{llcc}\text { (Log sel) } \\
\text { Pengurangan jumlah bakteri }\end{array}$ & 15 & 3 & 0 \\
\begin{tabular}{l} 
(CFU/ml) \\
\hline
\end{tabular} & & & \\
\hline
\end{tabular}

Ayam umumnya memproduksi kotoran 0.06-0.15 kg per hari (Yahya et al. 2017). Kebersihan kandang peternakan dipengaruhi oleh kotoran hewan ternak, yang mengandung mikroorganisme pathogen, seperti verocytotoxigenic E. coli (VTEC). Lantai kandang peternakan yang kotor, menurut Anitasari (2008) meningkatkan kemungkinan infeksi VTEC hingga 21 kali lebih besar daripada kandang dengan lantai bersih. Dengan demikian kebersihan dan sanitasi kandang ayam perlu diperhatikan agar terbebas dari mikrob patogen, penggunaan ekoenzim dari limbah jeruk segar dapat mengu-rangi jumlah mikrob yang terdapat di kandang ayam sehingga berpotensi digunakan sebagai pembersih kandang yang ramah lingkungan menggantikan bahan kimia sintetik.

\section{KESIMPULAN}

Ekoenzim cairan pembersih kandang dari limbah jeruk (Citrus sp.) memiliki kemampuan untuk menghambat pertumbuhan Escherichia coli dan Staphylococcus aureus melalui uji konfrontasi di laboratorium. Pengujian efektivitas ekoenzim di kandang ayam dapat menurunkan jumlah bakteri lima kali lebih banyak dibandingkan detergen untuk luasan yang sama.

\section{UCAPAN TERIMA KASIH}

Ucapan terima kasih kepada Direktorat Jenderal Pendidikan Tinggi, Kementerian Pendidikan dan Kebudayaan Republik Indonesia yang telah membiayai penelitian ini melalui Program PKM RE tahun 2021. Terima kasih kepada Fakultas Peternakan, Institut Pertanian Bogor yang telah memfasilitasi pengerjaan penelitian di laboratorium dan kandang.

\section{DAFTAR PUSTAKA}

Anitasari, P. 2008. Hubungan antara kondisi sanitasi kandang ternak dengan kejadian diare pada peternak sapi perah di Desa Singosari Kecamatan Mojosongo Kabupaten Boyolali. Skripsi. Universitas Muhammadiyah Surakarta, Solo.

Ardana, I.B.K. 2011. Strategi pencegahan penyakit infeksius pada peternakan broiler berbasis laboratorium. Buletin Veteriner Udayana. 3(1): 51-59.

Azizah, R \& R. Zuroida. 2018. Sanitasi kandang dan keluhan kesehatan pada peternak sapi perah di Desa Murukan Kabupaten Jombang. Jurnal Kesehatan Lingkungan. 10(4): 434-440.

Etienne, A., M. Genard, P. Lobit, D. Mbeguie-Ambeguie, \& C. Bugaud. 2013. What controls fleshy fruit acidity? A review of malate and citrate accumulation in fruit cells. Journal of Experimental Botany. 64(6), 14511469.

Gelgel, K.T.P. \& P.H. Sudipa. 2020. Efikasi sterilisasi dan desinfeksi kandang untuk mengurangi infeksi bakteri. Buletin Veteriner Udayana. 12(1): 61-66.

Kasnodihardjo \& K. Friskarini. 2013. Sanitasi lingkungan kandang, perilaku, dan flu burung. Kesmas: National Public Health Journal. 8(3):139-144. doi:10.21109/ kesmas.v8i3.357.

Krisnawan, A.H., R. Budiono, D.R. Sari, \& W. Salim. 2017. Potensi antioksidan ekstrak kulit dan perasan daging buah lemon (Citrus Lemon) local dan impor. Seminar Nasional 2017 Fakultas Pertanian UMJ Pertanian dan Tanaman Herbal Berkelanjutan di Indonesia”. 28 Desember 2017, Surabaya, Indonesia. 30-34.

Kumar, A., H.K. Sadhya, E. Ahmad, \& S. Dulawat. 2020. Application of bioenzyme in wastewater (greywater) treatment. International Research Journal of Engineering and Technology. 7(5):2886-2890. 
Larasati，D., A.D. Astuti, \& E.T. Maharani. 2020. Uji organoleptik produk eco-enzyme dari limbah kulit buah (studi kasus di Kota Semarang). Jurnal Seminar Nasional Edusainstek. 278-283.

Madigan, M.T., J.M. Martinko, D.A. Stahl, \& D.P. Clark. 2012. Biology of Microorganisms. Benjamin Cummings, San Fransisco.

Rasit, N., L.H. Fern, \& W.A. Ghani. 2019. Production and characterization of ecoenzyme produces from tomato and orange wastes and its influence on the aquaculture sludge. International Journal of Civil Engineering and Technology. 10(3): 967-980.

Rochyani, N., R.L. Utpalasari, \& I. Dahliana. 2020. Analisis hasil konversi eco enzyme menggunakan nenas (Ananas comosus) dan pepaya (Carica papaya L.). Jurnal Universitas PGRI Palembang. 5(2): 135140.
Seniati, Marbiah, Nurhayati. 2017. Kajian uji konfrontasi terhadap bakteri patogen dengan menggunakan metode sebar, metode tuang dan metode gores. Jurnal Galung Tropika. 6(1): 42-48.

Win, C.Y. 2011. Eco-enzyme Activating the Earth's Self Healing Power. Kuala Lumpur: Summit Print SDN. BHD; 6,8,9-14.

Yahya, Y., Tamrin, \& S. Triyono. 2017. Produksi biogas dari campuran kotoran ayam, kotoran sapi, dan rumput gajah mini (Pennisetum Purpureum cv. Mott) dengan sistem batch. Jurnal Teknik E rrtanian Lampung. 6(3): 151-160. 